\title{
教室における頸部リンパ節生検の検討
}

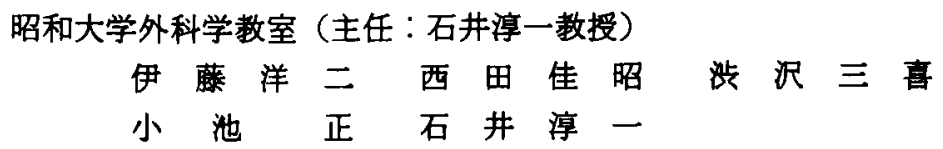

\section{CLINICAL STUDIES ON THE OPEN BIOPSY OF THE CERVICAL LYMPH NODES}

Yoji ITO, Yoshiaki NISHIDA, Miki SHIBUSAWA

Tadashi KOIKE and Jun-ichi ISHII

Department of surgery, showa University, School of Medicine

(Director : prof. Jun-ichi ISHII)

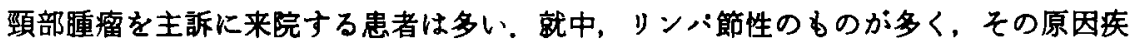
患も種々あり，鑑別診断む容易でない。この為リンバ節生検は診断手段として，あるい は治療方針を立てる上で重要である．当教室において，過去 5 年間に外来で施行された 频部リンバ節生険71例について検討した．結果は，1）結核性リンハ節资は，最近は减少 㑯向にあると言われているが，まだまだ高頻度にみられ，各年龄居に平均していた，2）

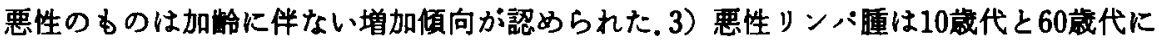
ピークがあり， 2 峰性を示した。

索引用浯：頸部属瘤, リンバ節生検

\section{I. 緒}

日常の外来診療で頚部の腫瘤を主訴とする患者に接 することは非常に多く，また正確な診断を下すのb困 難である. 頸部リンパ節腫脹は他の表在性リンパ節に 比一触知し易く，悪性疾患の初発症状となることる多 いまた顡部リンパ節腫脹をきたす原因疾患る種々あ り，頭頸部に限らず，胸部，腹部疾患さらに全身性疾 患と数限りなく举げられよ5。しかし，それらの疾患 を臨床所見や理学所見のみから鑑別することは容易で はない.これらのことからも，リンハ節生検は非常に 有力な診断手段と思われ，実際に施行される機会も多 い. 加えて悪性廆晹の治㞠方針にる利用されるよ5に なった現在リンパ節生検は多目的化してきていると いえよ5。

そこで著者らは，過去 5 年間に外来で施行された頸 部リンパ節生検について検討し，若干の考察を加えた ので報告する。

II. 対 象

昭和51年 1 月から昭和55年 12 月までの 5 年間に当数
室外来において施行された表在性リンバ節生検数は 112例で,らち頸部リンバ節生検の行なわれた71例につ

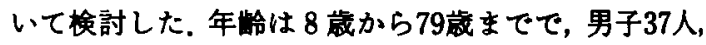
女子34人であった。

\section{III. 結 果}

表 1 に, 生検のなされた112例の表在性リンパ節の部 位を示す。顠部リンバ節生検数は71例で半数以上を占 めている，次いで甪径部は22例，鎖骨上窝および腋㻤 部はそれぞれ 6 例，13例であった，頸部リンバ節生検

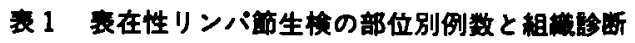

\begin{tabular}{|c|c|c|c|c|c|}
\hline $\begin{array}{l}\text { 粗新新 } \\
\text { 部位 }\end{array}$ & & 性 & & 性 & 計 \\
\hline 頚 部 & & $63 \%$ & & $37 \%$ & $71100 \%$ \\
\hline 銷骨上荝 & & $50 \%$ & 3 & $50 \%$ & $6100 \%$ \\
\hline 搌要部 & & $61 \%$ & 9 & $39 \%$ & $13100 \%$ \\
\hline 鼠任部 & & $73 \%$ & & $27 \%$ & $22100 \%$ \\
\hline
\end{tabular}




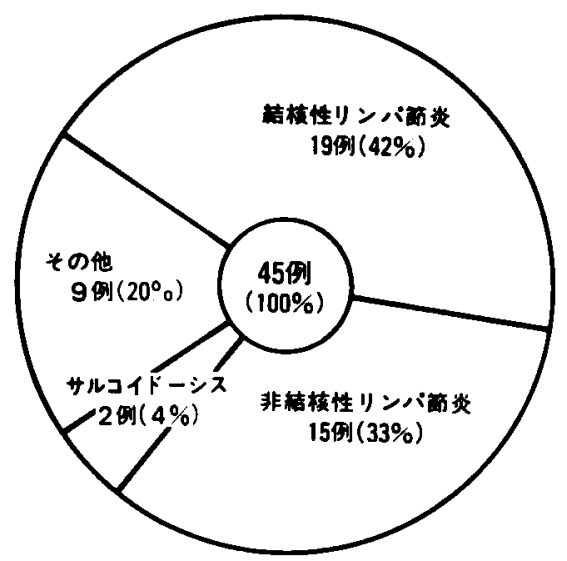

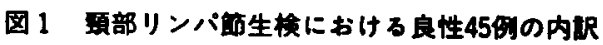

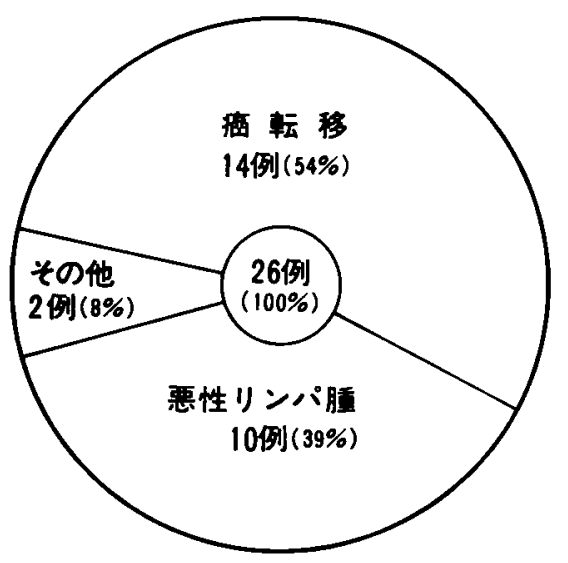

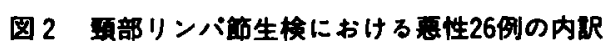

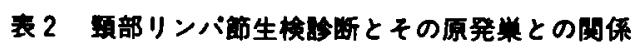

\begin{tabular}{|c|c|c|}
\hline 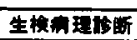 & 原突覃 & 利 \\
\hline 腺癌 & 甲状腺 & 5 \\
\hline 腺渵 & 角 & 3 \\
\hline 俆㾝 & 肺 & 2 \\
\hline 腺痤 & 食道 & 1 \\
\hline 局平上皮蝠 & 不 明 & 3 \\
\hline
\end{tabular}

71例のうち良性は45例(63\%)，転移性腫㾂，悪性リン バ腫などの悪性のすの26例（37\%）であった。

良性45例の内訳は，結核性 ンンハ節炎が19例で42\% と最も多く，非結核性リンパ節炎が15例，33\%であっ た。結核性リンパ節炎の男女比は 1：2で女子に多 かった(図 1)，悪性26例のうち，癌の転移によるもの 14例で $54 \%$ ，悪性リンバ重が10例で39\%であった（图 2).

生検の病理学的診断で癌転移と認められた症例の原 発巣は，表 2 に示すよ5に甲状腺が 5 例で全体の $36 \%$ を占めた。他に胃, 肺, 食道す認められ, 病理組織学 的には腺癌が多かった. 男女比では男子 9 例に比し女 子 5 例であった。原発巣が不明のものが 2 例にみられ た.

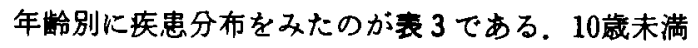
および10歳代は生検数が少ないが, 他の年代の生検数 ははば平均していた。良性のうちで非結核性リンバ節 炎は20葴代から50歳代に多いのに比へ，結核性リンパ

表 3 頭部リンパ慨生模の年代別疾息分布

\begin{tabular}{|c|c|c|c|c|c|c|c|c|c|}
\hline & 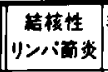 & 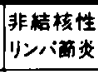 & \begin{tabular}{|c|} 
サルコイト \\
$-\Sigma$ -
\end{tabular} & $\begin{array}{l}\text { 丕 明 } \\
\text { 七の地 }\end{array}$ & 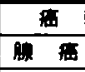 & 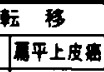 & 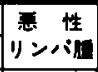 & 地 & It \\
\hline $0-9$ & & 1 & & & & & & & 1 \\
\hline $10-19$ & 1 & & & & & & 1 & & 2 \\
\hline $20-29$ & 3 & 6 & & 1 & & & 2 & & 12 \\
\hline $30-39$ & 5 & 3 & & 2 & 1 & 1 & & & 12 \\
\hline $40-49$ & 3 & 3 & 2 & 1 & 4 & & & & 13 \\
\hline $50-59$ & 3 & 2 & & 1 & 3 & 1 & 2 & & 12 \\
\hline $60-69$ & 2 & & & 3 & 2 & 1 & 3 & & 11 \\
\hline $70-$ & 2 & & & 1 & 1 & & 2 & 2 & 8 \\
\hline
\end{tabular}




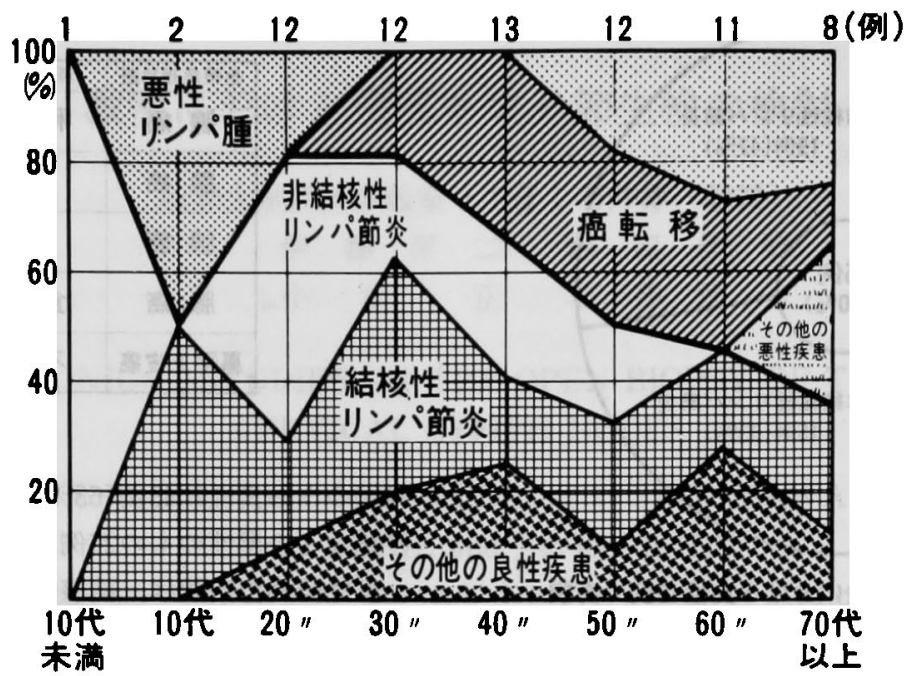

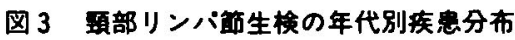

節炎は70墄以上の高龄者まで平均して認められ，その ビークは30葴代であった。悪性のむのでは癌転移が30 歳代で 2 例，40歳代で 4 例，50歳代で 4 例，60歳代 3 例，70歳以上 1 例と癌年龄にはぼ一致して增加が認め られた。悪性リンバ腫は10歳代から20歳代に 3 例，50 感代から70歳代にかけ 7 例と二蜂性を呈したが，特に 高齢者に多い傾向がみられた．40葴以上の例数は43例 であるが，このちち悪性のものは19例，49\%を占めて いた。

図 3 は各年代別に疾患の割合いをみたものである か，生検数の平均している20歳代以降では，明らかに 悪性のるのが加龄に伴い增加しているのがわかる。 た結核性リンバ節炎の占める割合いは各年代に平均し ているが，特に30歳代でその割合いが高かった。

\section{IV. 考 实}

频部リンバ節腫脹を来たす疾患は数多い。これら疾 患の正確な診断を臨床所見, 局所所見などから下すこ とは難しい，そこで，生検を行ない組織学的に確定診 断を下すことが多くなり，さらに治療方針の決定を目 的として生検を行ならことも多い。

過去 5 年間に教室の外来で施行された頸部リンパ節 生検を検討したか，単純性リン八節炎，結核性リンパ 節炎，癌転移，覀性リン八腯などが多くみられた。

化学療法の進歩に伴い, 結核性は近年減少している と言われているが，結核性リンバ節炎はなお高頻度に みられ，辻ら 本らは炎症の $40 \%$ としている。教室では $27 \%$ を占め， これらの報告とはばー致していた。
男女比では 1：2 と女性に多く，年龄では30歳代に 多くみられた。松下了は同様に1：2で女性に多いと し，症例の約半数は20歳代で年をとるにつれて減少す ると述へでおり，更に最年長を66歳としている，塚田 らけす10代から30代までが61.8\%を占めたとしてい る.これらはいずれる昭和 40 年, 41 年の報告であるが， これに対し，福田 (5)は平均年龄42.5歳と年龄の高龄 化を報告している，数室例です10歳代から30歳代が半 数を占めていたものの，各年龄首に広䇢囲にわたって おり，最年長は74歳の女性であった。結核性リンハ節 炎は隇少傾向にあるとはいえ，なお高頻度にしかす高 路者にもみられるので，診断上注意を要すると思われ る.

結核性リンバ節炎は一般に病悩期間が長い。これは， 一般状態がそれ程重篤でないこと，また血沈や胸部レ 線像です大きい変化をみないことなどからすらなずけ 上5. 病巣は片側性のことが殆んどで，珠数状にいく つかのリン八節を触知するが，病期によっては融合し ていることもある。これらの特徵から，結核性リンバ 節炎の診断は比较的容易と思われる. 生検時には融合 したリンパ節を一塊として切除しなければならない。 一部のるを切除すると，症状の急性増悪を招いたり， 難治性瘦孔を形成することも多く，患者医師相方に とって苦痛となる。

悪性リンパ腫は，悪性26例のうち39\%を占めた，内 わけは細網肉腫 5 例, Hodgkin 2 例, リンバ肉庫 2 例, 滤胞性リンバ腫 1 例であった。

悪性リンパ董は40歳代から60歳代に好発することが 
知られているか，Hodgkin は比較的若年者に多い様て ある. 教室では20歳代 2 例，50歳代 2 例，60歳代 3 例， 70葴以上 2 例となっており二峰性を示していた，最年 少は15歳の細網肉腫で，最年長は77歳の Hodgkin で あった。

悪性リンバ腫が頸部腫㿔を初発症状とすることは多 い.これは湏部リンバ節が他の表在性リンパに比べ隀 脹し易く，患者の自己診断すあり，これが初発症状と

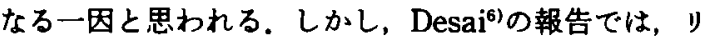
ンバ節性の要性リンハ腫の好発部位としては頙部が最 多であるが，頸部リンバ節限局型は28\%でリンバ節以 外の哭器を原発巣とすることが多いとしている。

本症の診断は，無痛性で皮瓦に発赤や熱感を伴うこ とが稀で，弾性硬，表面平滑，多リンバ節型などの特 改から触診が有効である。しかし，悪性リンバ腫の場 合に臨床的に診断し得たとしても，その組織学的診 断が治療や予後に大きな比重を占めるので，生模が必 す必要となってくる．生検時には比較的大きなりンバ 節を完全に摘出することが大切である，Butler"作最 あ取り易いリンパ節ではなく最す大きいリンパ節を選 ぶべきで，しかも，挫滅したりすることなく完全な型 で摘出すべきであると述べている．摘出後はすみやか に漂本を固定しなければならず，固定をよくするため に割を入れておくことる必要である．さらに生検後の 病状の増悪の㲘念もあり，出来るだけ早く組織学的診 断を下す必要がある. Stump 法泉による細胞診は讯速 に診断が下せるので有用で，これを併用するのも良い と考える。

癌の頚部リンパ節転移では，原発巣の部位によって 転移を起こし易いリンバ節が認められている．鎖骨上 䆚のリンハ節は，胃腸などの消化器癌，肺癌，乳癌な どの枟移が多い，著者らは，鎖骨上窝リンハ節は転移 性腫䄈の可能性が高いことから，頸部リンバ節の対象 から除外した。

䫫部リンバ節の癌転移は頭䫫部からのものが圧倒的 に多く，福田ら 骨下の原発によるものが27\%とされている。これに対 し教室例では，鎖骨上方原発が 5 例 $36 \%$ ，鎖骨下方原 発が 7 例 $50 \%$ で, 原発不明のものが 2 例14\%であった。 これは，咽頭，喉頭などの疾患を有する患者は耳算咽 喉科や口腔外科を受診するためと考えられ，本教室の データと一致しないるのと思われる．教室例では甲状 腺原発が最る多く，その他は胃，肺，食道などであっ た。これは植草ら”，过ら”の報告と同様である。また
癌転移の組織診断で,その原発が不明である症例では， 組織型が扁平上皮癌であることが多く ${ }^{10)}$ ，教室でも原 発不明の扁平上皮癌を, 頸部に近い咽頭, 喉頭, 食道 に原発単を求めたが不明であった。

その他の悪性知では，77歳男性の Malignant hemangiopericytoma の 1 例と, 79歳男性の Malig. lymphoepithelioma の 1 例であった。

表在リン八節生検で良性と診断された72例のうち， 再度の生検や他の検査などを行ない，悪性と診断され たものが 4 例 $5.6 \%$ にみられた。生愉すべきリンバ節が いくつかある場合の選択や，生検の手技によっては， 適切な組織が採取されないといら危険性もあり，臨床 症状や䅅過などから悪性疾患が強く薙われる時には， 躊躇せず絽り返し生検を行ない，他の諸検査る加え， 総合的な診断を行ならことが望をしいと思われる。

所 ${ }^{11)}$ は、リンパ節組織の診断はど困難なるのはなく， 依頼検体の数す多いと述へてている. 更にButler")は,リ ンバ節の病理診断の難しさに，病变そのものの複雑さ に加え、リンバ節採取から標本作製に至るまでの各段 階での粗雑さを挙げている.

とかく外来手術といらと安易な気持ちになり易い が，充分に注意をはらい生検を行ない，臨床所見を数 多く提供し，病理医との協力によってょり正確な診断 が得られるすのと考光る。

\section{V.まとめ}

過去 5 年間に当教室外来において施行された頸部り ンハ節生検について検討した。各咨患の頻度，年踰， 診断，生検法などについて考察した。特に年龄分布に ついてみると，(1) 結核性リン八節炎は各年齢層に平均 してみられ，减少傾向にあるとは言兄，なお高頻度に しか高龄者にもみられる. (2) 30歳代以降, 加齢に伴 ない悪性のすのか確実に増えている. (3) 悪性リンパ腫 は10歳代と60歳代にビークがみられた。などが特徽的 であった。

\section{文献}

1）过 泰邦, 調 亟治, 富田正雄他：リンバ節尰福, 外科診療， $13: 43-52,1971$.

2）藤本吉秀, 阿部秀一，岡 厚他：頚部悪性腫掦の 問题点, 外科診療, $13: 2-8,1971$.

3）松下良司：䅡部リン八腺結核の診断と治療，外科 診療, $14: 28-35,1966$.

4）塚田祐禧夫，石渡弘一，古泉桂四郎他：頝部リンハ 節結核の診断と治療について，外科診療， 7 ： 75-78, 1965. 
5）福田和馬, 考村 剛, 三好靑一他：䫓部隀瘤の臨床 病理学的模討, 外科診暴, $19: 68-73 ， 1977$.

6) Desai,P.B., Meher-Homi, D.R. and Paymaster, J.C. : Malignant lymphomas. Cancer, 18: 25 $-33,1965$.

7) Butler, J.J.: Non-neoplastic lesions of lymph nodes of man to be differentiated from lymphomas. Natl Cancer Inst. Monography, 32 : 233-255, 1969.
8）入久已，大宮㤎子：迅速標本のつくり方, Medical Technology, $7: 143-147,1979$.

9）植草 実, 米山桂八，三村 孝他：頚部腫瘤の臨床 診断, 外科診㞠, $13: 89-95,1971$.

10）竹田千里, 小野 黄, 海老原勉他: 原発不明がん, 㾔の臨床, $18: 185-190,1972$.

11）所安夫：臨床病理組織桧査法, 現代外科学大系, 中山書店, 1980 . 